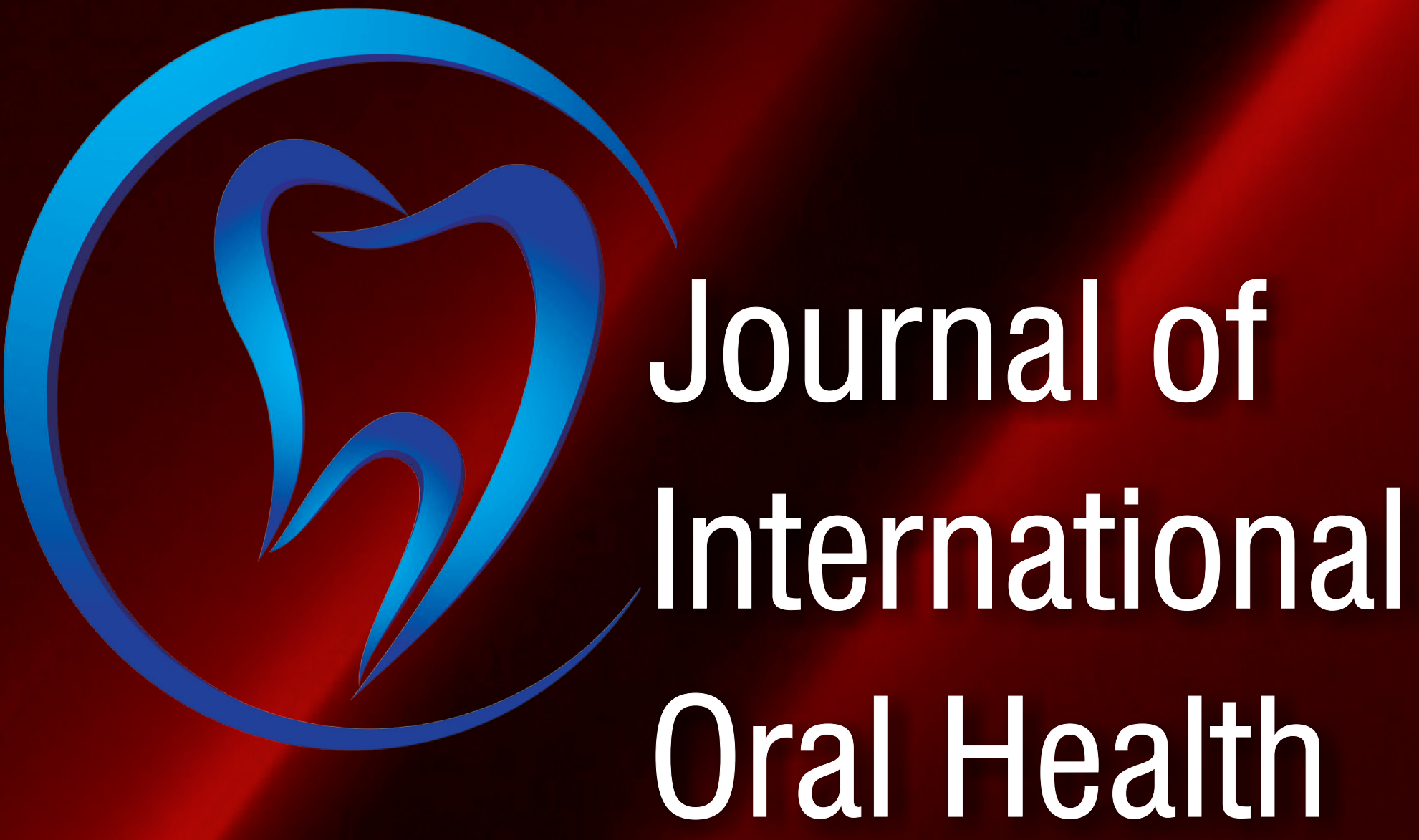

International Society of Preventive and Community Dentistry

Volume 11 • Issue 4 • July-August 2019

www.jioh.org 


\title{
A Review on the Prevention of Inflammatory Periimplant Diseases
}

\author{
Claudio Passariello ${ }^{1}$, Dario Di Nardo², Antonella Polimeni², Luca Testarelli² \\ 'Department of Public Health and Infectious Diseases, "Sapienza” University of Rome, Piazzale Aldo Moro 5, ²Department of Oral and Maxillo Facial Sciences, \\ "Sapienza" University of Rome, Via Caserta 6, Rome, Italy
}

\section{Abstract}

Background: An impressive number of dental implants are inserted worldwide. Evolution in dental implants and simplification of surgical techniques allowed a significant increase in the number of dentists involved in implant surgery. Most of them are general dentists, are not always sufficiently formed and experienced, frequently use low-quality implants, do not adopt the proper patient selective criteria, do not adequately monitor and maintain the inserted implants, and do not report their own statistics to the dental community. Consequently, the incidence of inflammatory periimplant diseases (IPDs) has progressively increased to values significantly higher than those previously indicated by the scientific literature. Materials and Methods: Two main literature searches were undertaken in October 2018 in the PubMed Website database. Only articles written in English and published from 2008 onward were considered; "Clinical Trial," "Meta analysis," "Observational study," "Review," and "Validation study" were selected as article type filters. The following keywords were used in the searches: "Peri implantitis prevention" and "Dental implant failure prevention." Results: Preventive measures are analyzed according to the different factors that can favor the occurrence of an infection. The factors are divided into (i) implant dependent, (ii) patient dependent, and (iii) surgeon dependent. Conclusions: Scientific and clinical data confirm that when materials are selected with care, patients are carefully evaluated for factors of risk and attitude to adhere to the necessary maintenance program, and operative protocols and maintenance programs are respected dental implants can be attractive and effective tools for oral rehabilitation. Nevertheless, dentists and patients should have greater awareness that in many cases the decision to utilize dental implants cannot be taken lightly.

Keywords: Periimplantitis, Periimplant Mucositis, Prevention

\section{INTRODUCTION}

Implant dentistry has emerged during the last decades as one of the most successful techniques for oral rehabilitation. ${ }^{[1-5]}$ Modern oral implants, if adequately inserted and maintained in rigorously selected and instructed patients, guarantee high success rates and long-term survival, although they can undergo inflammatory periimplant diseases (IPDs) and fail. ${ }^{[1,6-12]}$

In a recent review focusing at the evolution of implant dentistry and its future perspectives, Buser et al. ${ }^{\left[{ }^{[1]}\right.}$ properly evidenced that the picture suggested "by professional boards of periodontists that the incidence of biologic complications, and more specifically of peri-implantitis, may be up to $50 \%$, has shaken the dental community" and "holds a certain risk of damage to the reputation of implant dentistry."

\begin{tabular}{|l|l|}
\hline \multicolumn{2}{|c|}{ Access this article online } \\
\hline Quick Response Code: & Website: \\
& www.jioh.org \\
\hline & \\
\hline
\end{tabular}

According to the same authors, "the high prevalence of peri-implantitis reported by some authors is related to a scientific flaw." Nevertheless, daily clinical experience and several reports from the literature, which will be analyzed further in this article, indicate that the clinical relevance of IPD is underestimated as a consequence of different factors.

Success rates of dental implants are generally estimated according to results obtained by university-based groups with high clinical experience, performing maintenance and follow-up programs. ${ }^{[2-5]}$

\section{Address for correspondence: Dr. Dario Di Nardo, Department of Oral and Maxillo Facial Sciences, Sapienza University of Rome, Via Caserta 6, 00161 Rome, Italy. E-mail: dario.dinardo@uniroma1.it}

This is an open access journal, and articles are distributed under the terms of the Creative Commons Attribution-NonCommercial-ShareAlike 4.0 License, which allows others to remix, tweak, and build upon the work non-commercially, as long as appropriate credit is given and the new creations are licensed under the identical terms.

For reprints contact: reprints@medknow.com

How to cite this article: Passariello C, Di Nardo D, Polimeni A, Testarelli L. A review on the prevention of inflammatory periimplant diseases. J Int Oral Health 2019;11:165-71. 
During the last 10-15 years, the number of dentists involved in implant surgery has progressively expanded, with a significant increase of the number of general dentists who, in many cases, are not provided with specific clinical training and adequate skill and experience. ${ }^{[13,14]}$ Data of the literature show that when dental implants are positioned by dentists lacking diagnostic and clinical experience, training, and specific skills, they have significantly higher failure rates. ${ }^{[15-18]}$

The same period witnessed, at least in Europe, an exponential diffusion of the so-called "low-cost dental clinics" that, in many cases, found their expectation of commercial success on dental implant-based rehabilitations.

As most general dentists and those who work in "low-cost dental clinics" seldom perform dental implant maintenance programs and long-term follow-up of patients, and generally do not publish their own statistics in scientific journals, failures due to IPD in these cases are largely misunderstood.

Moreover, it must be considered that most of the studies performed in the past evaluated clinical outcomes of dental implants based on survival rates, and assumed that an implant is not failed until it is functionally valid. ${ }^{2-5,10-}$

${ }^{12]}$ Such an approach is misleading: in fact, a surviving implant is not necessarily a healthy implant. ${ }^{[19-22]}$

Recent reports show that when functionally valid implants (i.e., dental implants loaded with a prosthesis in the absence of subjective symptoms and functional limitations) are examined for conditions of periimplant tissues, the prevalence of periimplantitis results as high as about $35 \%$ at the patient level and about $20 \%$ at the implant level. ${ }^{[23-25]}$

Once considered that only two main causes of progressive periimplant bone resorption have been extensively investigated in the past (i.e., functional overload and infection), and that at present most authors consider that the role of overload (in the absence of inflammation) has been largely overestimated ${ }^{[26,27]}$, it must be concluded that periimplantitis is by far the most relevant menace to periimplant tissue health ${ }^{[6,7,28]}$ and that concrete, coordinate measures should be adopted in everyday practice to effectively reduce its incidence.

\section{Materials and Methods}

This non-systematic review intended to analyze selected literature reports dealing with technical and clinical procedure having an influence on the prevention of IPD in order to give the reader synthetic and updated key information ready to be applied to daily clinical practice and to perform implant dentistry with high probability of long-term success.

It was consequently decided to perform literature searches using only general terms expected to be as inclusive as possible. Such an approach could have limited the possibility to retrieve articles dealing with very specialized aspects of the argument and with basic science knowledge, which nevertheless were not within the aims of this review article.

Two main literature searches were undertaken in October 2018 in the PubMed Website database. Only articles written in English and published from 2008 onward were considered; "Clinical Trial," "Meta analysis," "Observational study," "Review," and "Validation study" were selected as article type filters. The following keywords were used in the searches: "Peri implantitis prevention" and "Dental implant failure prevention." The two searches retrieved 213 and 159 articles, respectively, including several replicates. A first selection was made by the authors by reading the titles and abstracts from these results to identify articles dealing with the selected topics of this review. For articles appearing to be of interest, or for which the title and abstract did not allow to make a clear decision, the full report was assessed. In this way, 123 articles were selected overall. Reference lists of these articles were hand-searched for additional articles.

The last complementary checkup for newly published articles within the topic was performed in April 2019.

\section{Discussion}

IPDs are bacterially driven inflammatory processes that can be favored by different factors, thus requiring an articulated net of preventive measures to be carefully adopted. These factors can be divided into (i) implant dependent, (ii) patient dependent, and (iii) surgeon dependent.

\section{Implant-dependent factors}

At present, a plethora of different dental implant systems are available worldwide. Only in Italy, about 60 dental implant manufacturers are active and in several cases these implants are inadequately designed and poorly controlled.

Studies performed between the middle 1980s of the last century and the beginning of the new millennium allowed to identify moderately rough titanium surfaces as the gold standard for optimal osseointegration. ${ }^{[1,29-32]}$ The growing need for multiple prosthetic connection solutions determined success of the two-piece implant systems, although creation of the implant-abutment interface (IAI) revealed risky by enabling bacteria to penetrate inner parts of the implant, which can act as an infective reservoir to promote IPD. ${ }^{[33-35]}$

Although internal hexagon connections characterizing modern implants make the IAI less accessible to bacteria, and although the introduction of conical connections enabled to significantly reduce gap dimensions at the IAI, ${ }^{[36]}$ all types of connections, when tested under charge or evaluated clinically, show some degree of bacterial microleakage. ${ }^{[37,38]}$ 
Experimental data show that bacterial microleakage is inversely proportional to torque used to tighten the abutment, ${ }^{[36,39]}$ and that abutments made of zirconia $^{[40]}$ and castable abutments ${ }^{[4]}$ enhance the risk. It can consequently be concluded that titanium-to-titanium pre-machined abutments should be privileged.

The region where fixture, abutment, and prosthesis meet is a very delicate one: different materials come in intimate contact in direct proximity to the place where gingival epithelium, connective tissue, and bone work together to repair/maintain tissue integrity. Such a variety of juxtaposed surfaces is very attractive for many different bacterial species, thus contributing to enhance infective risk. ${ }^{[42]}$

It is not by chance that a lot of work was performed to understand the histological characteristics of periimplant marginal tissues and to optimize/modify the implant collar so that marginal bone is preserved and bacterial biofilm formation is minimized. Moderately rough titanium surfaces play an osteoconductive role and undergo optimal osseointegration without enhancing bacterial biofilm accumulation. ${ }^{[43]}$ Rough titanium collars minimize marginal bone remodeling ${ }^{[44]}$ and promote bone and soft connective tissue formation. ${ }^{[45]}$ Marginal bacterial biofilm accumulation is undoubtedly the necessary condition for IPD initiation and the possibility for bacteria to access intra-implant reservoirs is probably the way they use to have an easier access to marginal bone.

Different strategies to reduce the susceptibility of dental implants to bacterial colonization have been investigated. Laser ablation of titanium implant surfaces was shown to reduce the amount of biofilm formed by different pathogens as compared to sandblasted titanium surfaces. ${ }^{[4]}$ Anatase-coated implant collars were shown to reduce marginal bone loss and to prevent colonization by Tannerella forsythia, as compared to standard implants. ${ }^{[47]}$

Bacterial biofilms formed in a 96-hour time course on titanium discs coated with zinc oxide or zinc oxide and hydroxyapatite nanoparticles were reduced in mass and viability as compared to uncoated titanium. ${ }^{[48]}$

Glassy coatings enriched with antimicrobials significantly reduced bacterial colonization of the surfaces and bone loss in an experimentally induced periimplantitis animal model. ${ }^{[49]}$

Shahi et al. ${ }^{[50]}$ immobilized tetracycline-containing fibers at the surface of implants obtaining a significant, although transient, antibacterial activity. ${ }^{[50]}$ Wang et al. ${ }^{[51]}$ developed a silica-based gentamicin nanodelivery system cross-linked to oxidized titanium.

Binding of bioactive peptides to titanium is being actively investigated to obtain long-lasting antibacterial activity and to speed up osseointegration processes in the absence of toxic effects. ${ }^{[52,53]}$
Considered that IPDs are sustained by different microorganisms and characterized by different pathogenic mechanisms, it seems reasonable that the aforementioned strategies, once validated and appropriately coupled, could prove effective in reducing the incidence of IPD, and that implants with functionalized surfaces could be the materials of choice for cases characterized by relevant factors of risk.

\section{Patient-dependent factors}

The decision to submit a patient to a dental implantsupported rehabilitation should carefully consider factors relevant for the onset of IPD: (i) predisposing and risk conditions, and (ii) patient's care and attitude for oral hygiene.

Several authors addressed the question of risk factors and their relative and cumulative relevance in the decision process. ${ }^{[54-56]}$

The question whether a history of periodontal disease is a factor of risk for IPD or not is crucial and has been extensively debated in the literature and deserves special attention because periodontitis is a highly prevalent cause of partial/total edentulism (i.e., the condition that gives indication to implant-based rehabilitation). ${ }^{[57-59]}$

Most authors agree that a previous history of periodontitis is a factor of risk for IPD, ${ }^{[4-56,60]}$ and epidemiologic data indicate that patients with a history of periodontitis have a higher prevalence of periimplantitis than healthy patients, ${ }^{[54]}$ but the underlying mechanisms are not well defined. The assumption that the pathogenic microbiome of periodontally affected sites diffuses to the periimplant environment causing IPD is not scientifically supported. In patients treated for aggressive periodontitis, periodontal pathogens can colonize the periimplant environment in the absence of IPD. ${ }^{[61]}$ The microbiomes of adjacent periodontal and implanted sites are characterized by low degrees of congruence, and only a minority of dental implants adjacent to periodontal sites positive for putative pathogens included in the red complex resulted positive for the same microorganisms, with the most abundant species in the two environments being constantly distinct. ${ }^{[62]}$

Recent studies show that patients with a previous history of periodontal disease are less compliant to maintenance programs and oral hygiene measures than healthy subjects, and that consequently a history of periodontitis and its severity are factors influencing the compliance risk profile. ${ }^{[63]}$

Success rates for dental implants are influenced also by specific site-related factors including the periodontal condition and the level of bone crest in relation to the cementoenamel junction of adjoining teeth at the time of restoration. Interestingly, the risk associated with insertion of an implant adjacent to a periodontally affected tooth 
results significantly higher than the one associated with a generic history of periodontitis (odds ratios 8.0 and 2.4, respectively). ${ }^{[64]}$

Overall, when periodontal disease is considered as a risk factor in the implant decision-making process, it cannot be considered as a static factor but it should be rather related to a number of other parameters including patient's hygienic attitude and understanding of the relevance of maintenance, site-specific conditions, and the conditions of adjoining teeth.

Even in the absence of periodontal disease, inadequate oral hygiene and the presence of abundant dental biofilm are factors of risk for IPD. ${ }^{[65]}$ Patients with good oral hygiene develop IPD if implants are positioned so that their hygienic maintenance is difficult. ${ }^{[66]}$

A monocentric clinical study on 2673 implants in 1427 patients followed for a mean of 5.3 years showed a statistically significant association between secondary failures due to periimplantitis and individual attitude to oral hygiene. ${ }^{[67]}$

Cigarette smoking is considered by most authors as a major factor of risk for IPD. ${ }^{[56,68]}$ Negative effects of cigarette smoking are dose dependent, and smokers were estimated to have up to a three to four folds higher risk of developing periimplantitis than nonsmokers, ${ }^{[69]}$ associated with significant differences in the two microbiomes. ${ }^{[70]}$ Patients should consequently be encouraged to stop/ reduce smoking before implant therapy.

The role of alcohol consumption as a risk factor for dental implants is controversial. Several clinical studies addressed this question but only a minority of them identified alcohol consumption as an evident factor of risk. ${ }^{[71-73]}$ Unlike smoking and alcohol abuse, alcohol consumption is an extremely variable behavior (frequency, type, amount), and these variables are not constantly and univocally considered in the literature.

An experimental study in rats showed that prolonged and excessive alcohol intake significantly impaired osseointegration of titanium dental implants inserted in the femur. ${ }^{[74]}$

In a recently published review, the authors put in evidence that heavy alcohol consumption exacerbates the effects of tobacco. ${ }^{[75]}$ On the basis of available data, it appears reasonable to suggest caution in inserting dental implants in heavy alcohol consumers/abusers.

The role of diabetes as a factor of risk for IPD is widely debated. A recently published systematic review, specifically addressing this question, concluded that adequately controlled diabetes is not a factor of risk, whereas poor glycemic control favors impaired osseointegration, elevated risk of IPD, and implant failure. ${ }^{[76]}$

According to a meta-analysis performed by Monje et al., patients with diabetes have a $50 \%$ higher risk to develop periimplantitis, but not periimplant mucositis and, when only nonsmokers are considered, diabetic patients with hyperglycemia have a 3.39-fold higher risk for periimplantitis as compared to those with normal glycemia. ${ }^{[77]}$

In spite of a number of studies performed in different geographic areas, no substantial convergence on worldwide diffused gene polymorphisms correlated to an enhanced risk of IPD was evidenced. ${ }^{[78,79]}$

The potential risk associated with the occurrence of osteonecrosis of the jaw following implant therapy in subjects assuming bisphosphonates has been the object of intense debate in recent years.

Although bisphosphonate treatment is certainly associated with an increased incidence of osteonecrosis of the jaws, the role of dental implants as a trigger for this relevant complication is still uncertain. A recent review on this topic concluded that patients under oral bisphosphonate therapy can be submitted to dental implant therapy, provided all other concurring conditions of risk (age, diabetes, obesity, smoking, immunosuppressive therapies, poor oral hygiene) are carefully evaluated. ${ }^{[80]}$

\section{Surgeon-dependent factors}

The last two decades witnessed a significant evolution in implant materials and surgical procedures that have made implant insertion progressively easier, thus enlarging the number of dentists performing implant surgery. Although it is reasonable that simplified surgical procedures could have positively affected early outcomes of implant surgery, they have certainly contributed to reduce the mean experience of operators.

It is generally agreed that the learning curve of each surgeon is characterized by higher failure rates as compared to later periods. ${ }^{[17,81]}$ The impact of human factors on dental implant success is intuitive and was clearly demonstrated by monocentric studies evaluating the outcome of all implants placed during a period of time in a single clinical center. ${ }^{[51,82,83]}$ Albrektsson ${ }^{[82]}$ showed that one single surgeon, although experienced, was responsible for the majority of failed implants within the studied clinical center.

Studying a sample of 9582 implants consecutively placed between 2003 and 2011 during 3448 implant operations at one clinic, and followed up to end of 2015, Jemt ${ }^{[83]}$ observed that implant failures were associated to four significant factors, with the surgeon showing the highest impact on risk (hazard ratio $=2.50) .{ }^{[83]}$

Surgeon-dependent factors do not end with experience and adherence to protocols. The surgeon is responsible for patient selection and motivation, for surgical planning, for implant placement, and follow-up; he must interface with the prosthodontist and the oral hygienist for long-term maintenance of implants. 
Perioperative antibiotic prophylaxis addresses only earlyonset infections, whose incidence is low; consequently, the influence of antibiotic prophylaxis on success rates is minimal. At present, there are no established guidelines for antibiotic prescription in dental implant surgery. An investigation performed in Spain revealed that there is no consensus regarding antibiotic prophylaxis in implant dentistry and that the most commonly prescribed regimens are different from those recommend in the literature. ${ }^{[84]}$

Available data indicate that a single dose of $2 \mathrm{~g}$ of amoxicillin administered 1 hour before surgery is the regimen of choice for dental implant surgery with no need of further postoperative doses..$^{[9,85]}$

Long-term prevention of IPD requires a patientspecific maintenance program aimed at maintaining a healthy periimplant mucosa and promptly treating sites where periimplant mucositis occurs. ${ }^{[86]}$ Dental implant maintenance should include optimized daily oral hygiene, periodic implant examination and reevaluation of patientspecific risk factors, and periodic professional oral hygiene maintenance. Maintenance programs should be individually designed with a recall period not exceeding 6 months even in healthy, compliant patients. ${ }^{[63]}$

\section{Conclusion}

Dental implants are attractive and effective tools for oral rehabilitation, but dentists and patients should have greater awareness that in many cases the decision to utilize them cannot be taken lightly. Patients should be carefully evaluated for factors of risk and attitude to adhere to the necessary maintenance program. Dentists should carefully select materials, respect operative protocols, and constantly communicate with their staff to prevent IPD and periimplant tissue damage.

\section{Financial support and sponsorship}

Nil.

\section{Conflicts of interest}

There are no conflicts of interest.

\section{REFERENCES}

1. Buser D, Sennerby L, De Bruyn H. Modern implant dentistry based on osseointegration: 50 years of progress, current trends and open questions. Periodontol 2000 2017;73:7-21.

2. Buser D, Janner SF, Wittneben JG, Brägger U, Ramseier CA, Salvi GE. 10-year survival and success rates of 511 titanium implants with a sandblasted and acid-etched surface: A retrospective study in 303 partially edentulous patients. Clin Implant Dent Relat Res 2012;14:839-51.

3. Degidi M, Nardi D, Piattelli A. 10-year follow-up of immediately loaded implants with TiUnite porous anodized surface. Clin Implant Dent Relat Res 2012;14:828-38.

4. Fischer K, Stenberg T. Prospective 10-year cohort study based on a randomized controlled trial (RCT) on implant-supported full-arch maxillary prostheses. Part 1: sandblasted and acid-etched implants and mucosal tissue. Clin Implant Dent Relat Res 2012;14:808-15.
5. Gotfredsen K. A 10-year prospective study of single tooth implants placed in the anterior maxilla. Clin Implant Dent Relat Res 2012;14:80-7.

6. Lindhe J, Meyle J; Group D of European Workshop on Periodontology. Peri-implant diseases: Consensus report of the sixth European workshop on periodontology. J Clin Periodontol 2008;35:282-5.

7. Lang NP, Berglundh T; Working Group 4 of Seventh European Workshop on Periodontology. Periimplant diseases: Where are we now? - consensus of the seventh European workshop on periodontology. J Clin Periodontol 2011;38:178-81.

8. Albrektsson T, Buser D, Sennerby L. Crestal bone loss and oral implants. Clin Implant Dent Relat Res 2012;14:783-91.

9. Chrcanovic BR, Albrektsson T, Wennerberg A. Reasons for failures of oral implants. J Oral Rehabil 2014;41:443-76.

10. Chappuis V, Buser R, Brägger U, Bornstein MM, Salvi GE, Buser D. Long-term outcomes of dental implants with a titanium plasmasprayed surface: A 20-year prospective case series study in partially edentulous patients. Clin Implant Dent Relat Res 2013;15:780-90.

11. Dierens M, Vandeweghe S, Kisch J, Nilner K, De Bruyn H. Longterm follow-up of turned single implants placed in periodontally healthy patients after 16-22 years: Radiographic and peri-implant outcome. Clin Oral Implants Res 2012;23:197-204.

12. Vandeweghe S, Ferreira D, Vermeersch L, Mariën M, De Bruyn H. Long-term retrospective follow-up of turned and moderately rough implants in the edentulous jaw. Clin Oral Implants Res 2016;27:421-6.

13. Koole S, De Bruyn H. Contemporary undergraduate implant dentistry education: A systematic review. Eur J Dent Educ 2014;18:11-23.

14. Donos N, Mardas N, Buser D; 1st European Consensus Workshop in Implant Dentistry University Education. An outline of competencies and the appropriate postgraduate educational pathways in implant dentistry. Eur J Dent Educ 2009;13:45-54.

15. Ji TJ, Kan JY, Rungcharassaeng K, Roe P, Lozada JL. Immediate loading of maxillary and mandibular implant-supported fixed complete dentures: A 1- to 10-year retrospective study. J Oral Implantol 2012;38:469-76.

16. Morris HF, Manz MC, Tarolli JH. Success of multiple endosseous dental implant designs to second-stage surgery across study sites. J Oral Maxillofac Surg 1997;55:76-82.

17. Lambert PM, Morris HF, Ochi S. Positive effect of surgical experience with implants on second-stage implant survival. J Oral Maxillofac Surg 1997;55:12-8.

18. Jemt T, Olsson M, Renouard F, Stenport V, Friberg B. Early implant failures related to individual surgeons: An analysis covering 11,074 operations performed during 28 years. Clin Implant Dent Relat Res 2016;18:861-72.

19. Esposito M, Hirsch JM, Lekholm U, Thomsen P. Biological factors contributing to failures of osseointegrated oral implants. (I). Success criteria and epidemiology. Eur J Oral Sci 1998;106:527-51.

20. Chrcanovic BR, Kisch J, Albrektsson T, Wennerberg A. Factors influencing early dental implant failures. J Dent Res 2016;95:995-1002.

21. Palma-Carrió C, Maestre-Ferrín L, Peñarrocha-Oltra D, PeñarrochaDiago MA, Peñarrocha-Diago M. Risk factors associated with early failure of dental implants. A literature review. Med Oral Patol Oral Cir Bucal 2011;16:e514-7.

22. Sakka S, Baroudi K, Nassani MZ. Factors associated with early and late failure of dental implants. J Investig Clin Dent 2012;3: 258-61.

23. Kordbacheh Changi K, Finkelstein J, Papapanou PN. Periimplantitis prevalence, incidence rate, and risk factors: A study of electronic health records at a U.S. Dental school. Clin Oral Implants Res 2019;30:306-14.

24. Muñoz V, Duque A, Giraldo A, Manrique R. Prevalence of periimplant disease according to periodontal probing depth and bleeding on probing: A systematic review and meta-analysis. Int $\mathrm{J}$ Oral Maxillofac Implants 2018;33:e89-105.

25. Matarazzo F, Sabóia-Gomes R, Alves BES, de Oliveira RP, Araújo MG. Prevalence, extent and severity of peri-implant diseases. 
A cross-sectional study based on a university setting in Brazil. J Periodontal Res 2018;53:910-5.

26. Chang M, Chronopoulos V, Mattheos N. Impact of excessive occlusal load on successfully-osseointegrated dental implants: A literature review. J Investig Clin Dent 2013;4:142-50.

27. Duyck J, Vandamme K. The effect of loading on peri-implant bone: A critical review of the literature. J Oral Rehabil 2014;41:783-94.

28. Zitzmann NU, Berglundh T. Definition and prevalence of periimplant diseases. J Clin Periodontol 2008;35:286-91.

29. Buser D, Schenk RK, Steinemann S, Fiorellini JP, Fox CH, Stich H. Influence of surface characteristics on bone integration of titanium implants. A histomorphometric study in miniature pigs. J Biomed Mater Res 1991;25:889-902.

30. Buser D, Nydegger T, Oxland T, Cochran DL, Schenk RK, Hirt HP, et al. Interface shear strength of titanium implants with a sandblasted and acid-etched surface: A biomechanical study in the maxilla of miniature pigs. J Biomed Mater Res 1999;45:75-83.

31. Klokkevold PR, Johnson P, Dadgostari S, Caputo A, Davies JE, Nishimura RD. Early endosseous integration enhanced by dual acid etching of titanium: A torque removal study in the rabbit. Clin Oral Implants Res 2001;12:350-7.

32. Wennerberg A, Albrektsson T. On implant surfaces: A review of current knowledge and opinions. Int $\mathbf{J}$ Oral Maxillofac Implants 2010;25:63-74.

33. Tallarico M, Fiorellini J, Nakajima Y, Omori Y, Takahisa I, Canullo L. Mechanical outcomes, microleakage, and marginal accuracy at the implant-abutment interface of original versus nonoriginal implant abutments: A systematic review of in vitro studies. Biomed Res Int 2018;2018:2958982.

34. Liu Y, Wang J. Influences of microgap and micromotion of implantabutment interface on marginal bone loss around implant neck. Arch Oral Biol 2017:83:153-60.

35. Jansen VK, Conrads G, Richter EJ. Microbial leakage and marginal fit of the implant-abutment interface. Int J Oral Maxillofac Implants 1997; $12: 527-40$

36. Verdugo CL, Núñez GJ, Avila AA, San Martín CL. Microleakage of the prosthetic abutment/implant interface with internal and external connection: In vitro study. Clin Oral Implants Res 2014;25: 1078-83.

37. Koutouzis T, Mesia R, Calderon N, Wong F, Wallet S. The effect of dynamic loading on bacterial colonization of the dental implant fixture-abutment interface: An in vitro study. J Oral Implantol 2014:40:432-7.

38. Canullo L, Penarrocha-Oltra D, Soldini C, Mazzocco F, Penarrocha M, Covani U. Microbiological assessment of the implant-abutment interface in different connections: Cross-sectional study after 5 years of functional loading. Clin Oral Implants Res 2015;26:426-34.

39. Baggi L, Di Girolamo M, Mirisola C, Calcaterra R. Microbiological evaluation of bacterial and mycotic seal in implant systems with different implant-abutment interfaces and closing torque values. Implant Dent 2013;22:344-50.

40. Smith NA, Turkyilmaz I. Evaluation of the sealing capability of implants to titanium and zirconia abutments against porphyromonas gingivalis, prevotella intermedia, and fusobacterium nucleatum under different screw torque values. J Prosthet Dent 2014;112:561-7.

41. Rismanchian $M$, Hatami M, Badrian $H$, Khalighinejad N, Goroohi H. Evaluation of microgap size and microbial leakage in the connection area of 4 abutments with straumann (ITI) implant. J Oral Implantol 2012;38:677-85.

42. Perera-Costa D, Bruque JM, González-Martín ML, GómezGarcía AC, Vadillo-Rodríguez V. Studying the influence of surface topography on bacterial adhesion using spatially organized microtopographic surface patterns. Langmuir 2014;30:4633-41.

43. Ferreira Ribeiro C, Cogo-Müller K, Franco GC, Silva-Concílio LR, Sampaio Campos M, de Mello Rode S, et al. Initial oral biofilm formation on titanium implants with different surface treatments: An in vivo study. Arch Oral Biol 2016;69:33-9.

44. Mendonça JA, Senna PM, Francischone CE, Francischone Junior CE, de Souza Picorelli Assis NM, SottoMaior BS. Retrospective evaluation of the influence of the collar surface topography on peri-implant bone preservation. Int $\mathrm{J}$ Oral Maxillofac Implants 2017;32:858-63.

45. Cochran DL, Obrecht M, Weber K, Dard M, Bosshardt D, Higginbottom FL, et al. Biologic width adjacent to loaded implants with machined and rough collars in the dog. Int $\mathbf{J}$ Periodontics Restorative Dent 2014;34:773-9.

46. Drago L, Bortolin M, De Vecchi E, Agrappi S, Weinstein RL, Mattina R, et al. Antibiofilm activity of sandblasted and lasermodified titanium against microorganisms isolated from periimplantitis lesions. J Chemother 2016;28:383-9.

47. Cucchi A, Molè F, Rinaldi L, Marchetti C, Corinaldesi G. The efficacy of an anatase-coated collar surface in inhibiting the bacterial colonization of oral implants: A pilot prospective study in humans. Int J Oral Maxillofac Implants 2018;33:395-404.

48. Abdulkareem EH, Memarzadeh K, Allaker RP, Huang J, Pratten J, Spratt D. Anti-biofilm activity of zinc oxide and hydroxyapatite nanoparticles as dental implant coating materials. J Dent $2015 ; 43: 1462-9$.

49. López-Píriz R, Solá-Linares E, Rodriguez-Portugal M, Malpica B, Díaz-Güemes I, Enciso S, et al. Evaluation in a dog model of three antimicrobial glassy coatings: Prevention of bone loss around implants and microbial assessments. PLoS One 2015;10:e0140374.

50. Shahi RG, Albuquerque MTP, Münchow EA, Blanchard SB, Gregory RL, Bottino MC. Novel bioactive tetracycline-containing electrospun polymer fibers as a potential antibacterial dental implant coating. Odontology 2017;105:354-63.

51. Wang J, Wu G, Liu X, Sun G, Li D, Wei H. A decomposable silicabased antibacterial coating for percutaneous titanium implant. Int J Nanomedicine 2017;12:371-9.

52. Maeno M, Lee C, Kim DM, Da Silva J, Nagai S, Sugawara S, et al. Function of platelet-induced epithelial attachment at titanium surfaces inhibits microbial colonization. J Dent Res 2017;96:633-9.

53. Geng H, Yuan Y, Adayi A, Zhang X, Song X, Gong L, et al. Engineered chimeric peptides with antimicrobial and titaniumbinding functions to inhibit biofilm formation on Ti implants. Mater Sci Eng C Mater Biol Appl 2018;82:141-54.

54. Karoussis IK, Salvi GE, Heitz-Mayfield LJ, Brägger U, Hämmerle $\mathrm{CH}$, Lang NP. Long-term implant prognosis in patients with and without a history of chronic periodontitis: A 10-year prospective cohort study of the ITI dental implant system. Clin Oral Implants Res 2003;14:329-39.

55. Renvert S, Persson GR. Periodontitis as a potential risk factor for peri-implantitis. J Clin Periodontol 2009;36:9-14.

56. Dreyer H, Grischke J, Tiede C, Eberhard J, Schweitzer A, Toikkanen SE, et al. Epidemiology and risk factors of periimplantitis: A systematic review. J Periodontal Res 2018;53:657-81.

57. Ramseier CA, Anerud A, Dulac M, Lulic M, Cullinan MP, Seymour GJ, et al. Natural history of periodontitis: disease progression and tooth loss over 40 years. J Clin Periodontol 2017;44:1182-91.

58. Eke PI, Wei L, Borgnakke WS, Thornton-Evans G, Zhang X, Lu H, et al. Periodontitis prevalence in adults $\geq 65$ years of age, in the USA. Periodontol 2000 2016;72:76-95.

59. König J, Holtfreter B, Kocher T. Periodontal health in Europe: Future trends based on treatment needs and the provision of periodontal services-position paper 1. Eur J Dent Educ 2010;14:4-24.

60. Ferreira SD, Martins CC, Amaral SA, Vieira TR, Albuquerque BN, Cota LOM, et al. Periodontitis as a risk factor for peri-implantitis: Systematic review and meta-analysis of observational studies. J Dent 2018;79:1-10.

61. De Boever AL, De Boever JA. Early colonization of non-submerged dental implants in patients with a history of advanced aggressive periodontitis. Clin Oral Implants Res 2006;17:8-17.

62. Dabdoub SM, Tsigarida AA, Kumar PS. Patient-specific analysis of periodontal and peri-implant microbiomes. J Dent Res 2013;92:168S-75S.

63. Monje A, Wang HL, Nart J. Association of preventive maintenance therapy compliance and peri-implant diseases: A cross-sectional study. J Periodontol 2017;88:1030-41.

64. Kumar PS, Dabdoub SM, Hegde R, Ranganathan N, Mariotti A. Site-level risk predictors of peri-implantitis: A retrospective analysis. J Clin Periodontol 2018;45:597-604. 
65. Ferreira SD, Silva GL, Cortelli JR, Costa JE, Costa FO. Prevalence and risk variables for peri-implant disease in Brazilian subjects. $\mathrm{J}$ Clin Periodontol 2006;33:929-35.

66. Serino G, Ström C. Peri-implantitis in partially edentulous patients: Association with inadequate plaque control. Clin Oral Implants Res 2009;20:169-74.

67. Tecco S, Grusovin MG, Sciara S, Bova F, Pantaleo G, Capparé P. The association between three attitude-related indexes of oral hygiene and secondary implant failures: A retrospective longitudinal study. Int J Dent Hyg 2018;16:372-9.

68. Heitz-Mayfield LJ, Lang NP. Comparative biology of chronic and aggressive periodontitis vs. Peri-implantitis. Periodontol 2000 2010;53:167-81.

69. Heitz-Mayfield LJ, Huynh-Ba G. History of treated periodontitis and smoking as risks for implant therapy. Int $\mathbf{J}$ Oral Maxillofac Implants 2009;24 Suppl:39-68.

70. Pimentel SP, Fontes M, Ribeiro FV, Corrêa MG, Nishii D, Cirano FR, et al. Smoking habit modulates peri-implant microbiome: A casecontrol study. J Periodontal Res 2018;53:983-91.

71. Galindo-Moreno P, Fauri M, Avila-Ortiz G, Fernández-Barbero JE, Cabrera-León A, Sánchez-Fernández E. Influence of alcohol and tobacco habits on peri-implant marginal bone loss: A prospective study. Clin Oral Implants Res 2005;16:579-86.

72. Alissa R, Oliver RJ. Influence of prognostic risk indicators on osseointegrated dental implant failure: A matched case-control analysis. J Oral Implantol 2012;38:51-61.

73. Trullenque-Eriksson A, Guisado Moya B. Retrospective long-term evaluation of dental implants in totally and partially edentulous patients: Part II: periimplant disease. Implant Dent 2015;24:217-21.

74. de Deco CP, da Silva Marchini AM, Marchini L, da Rocha RF. Extended periods of alcohol intake negatively affects osseointegration in rats. J Oral Implantol 2015;41:e44-9.

75. Ryder MI, Couch ET, Chaffee BW. Personalized periodontal treatment for the tobacco- and alcohol-using patient. Periodontol 2000 2018;78:30-46.

76. Naujokat H, Kunzendorf B, Wiltfang J. Dental implants and diabetes mellitus - A systematic review. Int J Implant Dent 2016;2:5.
77. Monje A, Catena A, Borgnakke WS. Association between diabetes mellitus/hyperglycaemia and peri-implant diseases: Systematic review and meta-analysis. J Clin Periodontol 2017;44:636-48.

78. Nguyen-Hieu T, Borghetti A, Aboudharam G. Peri-implantitis: From diagnosis to therapeutics. J Investig Clin Dent 2012;3: 79-94.

79. Mo YY, Zeng XT, Weng H, Cen Y, Zhao Q, Wen X. Association between tumor necrosis factor-alpha G-308A polymorphism and dental peri-implant disease risk: A meta-analysis. Medicine (Baltimore) 2016;95:e4425

80. de-Freitas NR, Lima LB, de-Moura MB, Veloso-Guedes CC, Simamoto-Júnior PC, de-Magalhães D. Bisphosphonate treatment and dental implants: A systematic review. Med Oral Patol Oral Cir Bucal 2016;21:e644-51.

81. Block MS, Kent JN. Long-term follow-up on hydroxylapatite-coated cylindrical dental implants: A comparison between developmenta and recent periods. J Oral Maxillofac Surg 1994;52:937-43; discussion 944.

82. Albrektsson T. Is surgical skill more important for clinical success than changes in implant hardware? Clin Implant Dent Relat Res 2001;3:174-5

83. Jemt T. A retro-prospective effectiveness study on 3448 implant operations at one referral clinic: A multifactorial analysis. Part II: Clinical factors associated to peri-implantitis surgery and late implant failures. Clin Implant Dent Relat Res 2017;19:972-9.

84. Camps-Font O, Viaplana-Gutiérrez M, Mir-Mari J, Figueiredo R, Gay-Escoda C, Valmaseda-Castellón E. Antibiotic prescription for the prevention and treatment of postoperative complications after routine dental implant placement. A cross-sectional study performed in Spain. J Clin Exp Dent 2018;10:e264-70.

85. Lund B, Hultin M, Tranaeus S, Naimi-Akbar A, Klinge B. Complex systematic review-perioperative antibiotics in conjunction with dental implant placement. Clin Oral Implants Res 2015; 26:1-14.

86. Armitage GC, Xenoudi P. Post-treatment supportive care for the natural dentition and dental implants. Periodontol 2000 2016;71:164-84 